\title{
THE CULTURE OF COEXISTENCE AND PERCEPTION OF THE OTHER IN THE WESTERN BALKANS
}

\author{
Sibel Akova ${ }^{1, a}$ \\ Gülin Terek Ünal ${ }^{\mathrm{b}}$ \\ İzocam Ticaret ve Sanayi A.Ş. (IYEM) ${ }^{a}$ \\ Istanbul University Faculty of Communication ${ }^{b}$
}

Received: 02.01.2015

Accepted: 11.02.2015

\author{
Review papers
}

$\begin{aligned} \text { UDC: } & 316.7(497-15) \\ & 930.85(497-15) \\ & 94(497-15)\end{aligned}$

To live, alone and free like a tree, In brotherhood like a forest,

This longing is ours... Nazım Hikmet Ran

\begin{abstract}
Throughout the 550 year Ottoman rule over the Balkan lands, where even today internal dynamics threaten peace and justice, how and through what means the Ottoman Empire achieved consistency, security and peace is a question to which a number of political scientists, sociologists, communication scientists and history researchers have sought an answer. The most interesting point of the question is that the peoples of the Balkans, a living museum comprising a number of different ethnic groups and religious beliefs, have reached the point where the culture of coexistence has been internalised and dynamics have moved from the conflict of identities to cultural integration. The Balkans are a bridge to the East from Europe and indeed to the West from Turkey, incorporating a patchwork political and cultural geography, the geopolitical location and a richness of culture and civilization, being one of the areas attracting the attention of researchers from different disciplines and capturing the imagination of the peoples of the world throughout history. Balkan studies are almost as difficult as climbing the peaks in the areas and meaningful answers cannot be reached by defining the area on a single parameter such as language, culture or traditions, while the phenomenon of the other can also be observed within the culture of coexistence in this intricate and significant location. Different ethnic groups with different cultures, such as the Southern Slavs (Bosniaks, Montenegrans, Serbs, Croats and Slovenes) as well as Turks, Albanians, Bulgarians, Balkan Jews, Balkan Romany and Wallachians (Romanians and Greeks). Although these peoples may have different religious beliefs, in the ethnically rich Balkan region, religion, language, political and cultural differences are vital in the formation of a mosaic, making the discourse of coexistence possible and creating common values and loyalties, breaking down differences. The Serbian and Montenegrin peoples, belonging to the Greek Orthodox Church, the Croat and Slovene peoples belonging to the Catholic Church and the Muslin Bosniaks have shared the same lands and livee in coexistence throughout the historical process, despite having different beliefs. However, in some periods the other and the perception of the other have replaced common values, leading to conflicts of interest, unrest and religion based wars. After the breakup of the Yugoslavian Federal Socialist Republic, Slovenia, Croatia, the Former Yugoslav Republic of Macedonia, Bosnia and Herzegovina, Serbia, Montenegro and Kosovo, defined by the European Union as the Western Balkans, have established themselves as nation states of the stage of history. The scope of our study is these Western Balkan Countries, and we will use the terminology Western Balkans throughout.
\end{abstract}

Keywords: Western Balkans, Coexistence, Other, Identity, Cultural Integration

\footnotetext{
${ }^{1}$ Correspodence to:

Sibel Akova, Çalışma Y. Ekonomisti, İzocam Tic.ve San. A.Ş.

Teknik Pazarlama Müdürlüğü, İzocam Yalıtım Eğitim Merkezi

Phone: (0262) 75481 71-72 / 0530-469 2082

E-mail: akova@izocam.com.tr
} 


\section{A ETHNIC LABORATORY; THE WESTERN BALKANS}

The high and impassable Balkan mountains divide the land into areas, which were settled by the Balkan peoples with the difficulties of geographical proximity, who were unable to achieve the cycles of continuous and uninterrupted communication. The difficult geographical conditions limit the communication between the peoples living in different areas. This has led to the rise of linguistic, cultural, economic, religious, ideological, aesthetic, political, military and traditional differentiation between Balkan peoples in the historical process. The Balkans have assumed not only the role of being a global example for cultural richness, but also a metaphor for cultural conflict. The Balkans, covering South East Europe entirely, were under Ottoman rule for close to five and a half centuries, and having been influenced by Turkish culture, are referred to in the literature as the Turkish hinterland. Furthermore, the Balkans have been described as Turkey's periphery by a number of researchers, academics and politicians. After the Ottoman defeats in the 1st Balkan War, quickly followed by the 2nd Balkan War as well as the 1st World War, the Empire withdrew from the Balkans as in other areas, leaving the Turkish and Muslim population, the Evlad-1 Fatihan, in the Balkans. The Evlad-1 Fatihan are still living in the Balkans, and are perceived as the Other by the Balkan nations. Despite the ethnic, cultural and religious differences in the Balkans, many peoples have adopted the culture of coexistence and in a sense, creating a perception of dividedness and inconsistency while sustaining the possibility for open conflict. The coexistence culture prevalent in the Balkans has caused the Balkans to be renowned as an ethnic laboratory, making the Balkans relevant as an ethnic museum in the world of today. The identity conflicts, inconsistent and unjust structures of the Balkans lead to identity conflicts between different ethnic groups. The Balkans have been a regions that have continually been reformed according to the flow of political history.

Before the Ottoman period, the Balkan peoples had distinct ethnic roots within a more chaotic structure, while after the establishment of centralised Ottoman rule over the Balkans, rights related to languages and religions were protected by the state, accords were reached with the church and religious authorities, many concessions including tax cuts were granted and thanks to the consistent and peaceful government structure, valuing human values and the indi- vidual, the social and economic structures changed completely. With the retreat of the Ottoman Empire from the Balkans, between the Balkan peoples, where intricate relationships were prevalent within a mixed ethnic structure, nationalistic tendencies were rising with the support of external powers and delusions of inconsistency and backwardness were written into the fate of the region. In this period, Ottoman ties and Islamic doctrines were subverted, changing the current values of the time. This situation caused the Balkan peoples to become isolated and caused unsolvable issues. However, the power struggle of the dominant identities, beginning with the retreat of the Ottoman Empire from the Balkans in 1912, has continued into the present. The Islamic Ummah understanding and existing autonomous structure sustained by the Ottoman Empire caused cultural differences to prevail but have a minimal effect, while the discourse of multiculturalism promoted the culture coexistence over existing problems, reinforcing the harmony between communities and strengthening intercultural communication. "The native peoples of lands conquered by the Ottoman Empire were reorganized as local communities (millet) with their own laws and institutions. However, in these communities, the individual was nothing outside of the group. Individuals had no rights to chose or change their identities" (Doytcheva, 2013; 19). In the Balkans, within the historical process, many different civilizations, communities and cultures have existed. However, none of these cultures or civilizations have left a permanent trace, image or metaphor upon the Balkan regions as the Ottoman Islamic civilization has.

In the Ottoman period, the multi-ethnic Balkan communities were structured on a multicultural and multi-religious foundation. In the multicultural Balkan lands, where a culture of tolerance had been sustained in a way that is very rare, even in the society of today, the autonomy approach adopted by the Ottoman Empire allowed for cultural distinctions to be protected and differences to coexist without alienation. During the Ottoman period of cultural multiplicity, the emphasis was placed on protecting the differences and the sustainability of the existing multicultural structure rather than creating issues in the Balkans. Communities with distinct religious, ethnic and cultural identities were brought together in the Balkans under Ottoman rule; , however, they were able to protect their identities, living side by side, together and with the doctrine of coexistence, without being alienated, without conflict or being subject to pressure or force to adopt a culture other than their own. 
Communities with different ethnic identities and different cultures, as well as different religious beliefs and practices found the opportunity under the tolerance policy of the Ottoman Empire to practise their worship of the same god in different ways, benefitting from the humanistic approach of the times. Even today, it is possible to see Ottoman era mosques, churches and synagogues side by side all over the Balkans. The Ottoman Empire was governed according to the principle of equality among the 72 millets, successfully implementing the philosophy laid out in verse by Yunus Emre; he who does not see the 72 peoples as one, is against the truth even if a teacher to the people. The relationships between the Balkan communities did not consist solely of trade, but through reciprocal visits and neighbourly relations, the sharing of common living spaces, marriages between the communities, the celebration of national holidays jointly by all ethnicities, the tolerance and respect shown by communities towards the peaceful celebration of religious holidays of other ethnic groups and many other instances of such behaviour shows us that these communities were able to establish a common and brotherly culture of coexistence without compromising their own identities.

\section{COEXISTENCE AND SOCIAL DISTANCE IN THE WESTERN BALKANS}

In the Balkans, individuals and groups living in the same area, sharing the same language, same ethnic background and same history over the same period of time developed the culture of coexistence. In reality, the Balkans and indeed in the big picture, throughout the world, it is not possible to come across a homogenous group with the same culture, same ethnic roots, the same language, religion and identity. The differences existing in real life have led to the development of multiculturalism. Human beings forced to live with others with different and distinct identifies have learned to live in multicultural societies, moving from intercultural communication developing intercultural interaction in all walks of life, from the political sphere to the social cultural sphere, economic and cultural spheres. Living with differences has been a factor in the historical process promoting the voluntary nature of society, constituting the main factor in coexistence. Communities choosing to live with the existing variety in peace have affected each other, leading to change and transformation, developing, giving meaning to and adopting the culture of coexistence, while others that have perceived different colours and discourses as political and social issues have attempted the cultural integration of individuals and groups through forced and assimilation tactics.

Communities that approach cultural multiplicity and multiculturalism as a harmonious whole, with each part being equal, describe cultural differences as a rainbow, with each aspect of culture adding a colour to the rainbow, perceiving communities as different colours and living together. Communities with different ethnic identities living in the Balkans add meaning, colour and harmony to the rainbow of the Southeastern European region. The Balkan peoples have had different motifs at different periods in time, ranging from the ebru to the mosaic, and are gentile communities that have succeeded in living together in the same areas. For this reason, the symbolic meanings of the Balkan region and the Balkan communities and cultures are significant. During the Ottoman period, the view was one of an ebru, with no colours being separated from each other with strict lines, forming a harmonious whole. After the traumatic retreat of the Ottoman Empire from the Balkan lands and the erasure of Ottoman traces from social memory, these motifs have been replaced by mosaics, in which ethnic and cultural divides are drawn with hard lines and colours are separated from each other, leaving feelings such as love and hate tangled up in each other, independent but on the other hand, interconnected, with the additional aspects of social descriptions transformed into lifestyles of different groups whose unity has been rejected.

In societies described as modern, it is not realistic to refer to a single form of religion, culture, language or a single type of man. As social structure that approaches multiculturalism with respect and tolerance, in which every individual is free to experience his own cultural aspects, traditions and ancient rituals, where languages are freely used without any limitations, where religion is practised without any pressures, and where minorities are not alienation is the very definition of the ideal social state. Indeed, the acceptance of differences, recognition of linguistic, religious, cultural and ethnic nuances and an approach where differences are accepted in peace is the foundation of the multicultural approach. The individual starts life at birth with a number of characteristics such as gender, race, physiology, personality and sociological attributes that he is not able to choose. 
Some characteristics act as differentiating factors leading to alienation, while other include the individual in specific social or cultural groups with others having the same characteristic. Throughout history, from the emergence of Homo Sapiens until the present day, differences and similarities have separated or united individuals and communities, created conflicts and have been the source of unequal living conditions. These similarities and differences have affected all civil and vital perspectives, including the personalities, cultures, lifestyles and social statuses of individuals. Furthermore, these differences may also transform into collaboration, unity, togetherness, integration and coexistence, or alternately may also lead to social exclusion, alienation, discrimination, political conflict, hostility, unrest, competition and hatred. "From childhood we wear two layers of clothing. The first layer belongs only to the person and fits him well. This is his own identity. The second layer is a more comfortable cut and can accommodate many others. This is like a larger tent. This is the persons group or ethnic identity. The chosen trauma and victories, even the psychology of being a victim can be woven into the fabric of the tent" (Çevik, 2010; 86).

With the experience of the dynamics of coexistence, the Balkan peoples have maintained their own identities, religious, views, languages and lifestyles with the instinct to maintain and sustain these differences in religion and culture, living side by side in the same region, protecting their own forms of worship and cultural identities. With the identification of factors and values providing for social cohesion, the adoption of these factors and values by individuals and communities allow the coexistence of cultures and differences as a life discourse. The eradication of arguments negatively affecting this coexistence discourse is the main object in creating a living culture tolerant of differences. One of the arguments that may negatively affect the state of coexistence is that of assimilation policies implemented by governments and states to negate differences through limitations and create homogeneous societies. The multiculturalism that we see though almost all of history, especially in the Balkan region, has been expressed even in the face of situations that significantly alter societies, such as war and migration, with cultures meeting and integrating with each other, creating social compositions where different cultures have been able live together. Today, modern nation states are known as homogeneous entities, where the uniform model of man is conceptualised under the name of citizenship and even though individuality plays a large role, the Balkan states maintains their heterogeneous political and social structures. Balkan nation citizens coming from different ethnic backgrounds have been able to maintain the cultures, languages and traditions, being the structures of the ethnic roots to which they feel affiliation, as well as their freedom of religion and belief, also desiring and expecting the continuation of democratic rights and freedoms. The specific imagery, holidays and values as a metaphor of ethnic roots are expected to be valued on a national level, adopted and also given representational powers in the political arena, as a reflection of the struggle for existence. The nature of this struggle may lean towards autonomy or independence according to the condition of the period.

\section{THE PERCEPTION OF THE "OTHER" IN THE WESTERN BALKANS}

Known as an ethnic laboratory, in the Balkans the description of ethnicity is based mainly on religion rather than language, ethnic roots or race as in other localities. In the Balkans, differences based on ethnic or sectarian fault lines are felt in practice is social, economic, political, cultural, artistic and educational aspects of life. "Historical events and grudges have an important effect in shaping ethnic identities and in the relations between the ethnic groups. Although ethnicity is shaped through history, the roots are based in primitive times" (Abdülkadir Çevik, Politik Psikoloji, Dost Kitabevi, Ankara, s.73). The discourse of coexistence, side by side, embedded in each other, reinforces the practise of living with different identities and different religious groups for individuals. The basis of the coexistence construct is the sharing of areas adopted as a homeland with other groups under the same living conditions for centuries and the existence of a social structure open to variety. The existence of different beliefs and cultures is only possible with the perception of differences and the variety born out of these differences as a source of richness instead of alienation and exclusion. The perception of differences not as the reason for separation, but as a way of life in which variety shapes the opportunities that are open to individuals, allows the formation of a feeling of belonging in nearly every segment of society. Indeed "the definition of the Other is an inseparable part of the definitions of Me and Us" (Lewis, 2000; 83). In other words, the other is symmetrical to "us". In the construction, definition and struggle for existence of identities, existing differences are perceived as the other in order to prove validity by drawing borders for the conceptual framework between the self and aspects that are different. 
Levinas, writing about alienation and the other, asked who would the other be and defined the concept of the other as the distinction between alter and alius in Latin, describing the meaning as being faced with the other (Levinas, 1961:9). The concept of the other indicates a distinct perception of ethnicity and culture. At the same time, although the exact criteria may change between different societies, characteristics such as gender, class, caste, ethnicity, race, religion, political orientation and sub culture membership may be used as the basis for alienation. The concept of the other is referred to within cultural theories in the literature, symbolising the expression of differences established by a group against the self or ego. The level of communication between us and the other also affects instrumentive factors such as the perception of cultural differences, conflicts between lifestyles, shaping of coexistence doctrines, achievement of social peace as well as the development of political and social conflicts, prejudice regarding a specific group and the justification of control mechanisms upon a group that is perceived as being different. As in many other communities throughout history, the different ethnic groups living in the Balkans have been thrown into the great melting pot of the dominant culture, being replaced by the new understanding of cultural multiplicity. Ethnicity, in the most basis sense, is defined as belonging to a group with a common cultural past, culture and spoken language. The term ethnicity implies a necessity for a higher proportion of participation, at the highest level of identity and self-awareness. Ethnicity expresses a level of identity beneath that of a nation, with more authentic and less developed borders. Societies incorporating one or more different ethnicities sharing the same borders can form a nation and develop the discourse of political identity.

Instead of doubting the other identity, of which the structure and qualities are not entirely known and for this very reason is open to negative perceptions, the acceptance of differences that do not intervene into "our" living space, do not have to be kept under control and are not perceived as being hostile, will accelerate the transition into cultural multiplicity. The level of the separation between us and the other, the dimensions of the alienation argument, stereotypes, ethnocentrism, social distance and prejudice, alongside other various factors, affect the representation of differences, finding their way into political and social discourse and therefore affect the development of cultural multiplicity. The unity of the Balkan communi- ties with common codes of culture has been affected by the cultural, political, economic and social change observed all over the world. The effects, speed and scope of transition and transformation may also lead to various breaking points. Issues that may affect coexistence practices, namely genocide, ethnic discrimination, identity threats, social exclusion, and alienation can lead to social isolation issues, social distance and social comparison problems. The achievement of equilibrium, democracy and the protection of rights between the peoples of different ethnic origin living in the Balkans in different points in history, leading to the facilitation of permanent peace, has not been a quick and easy process. Although ethnic conflicts that can be read as sectarian conflicts reaching the level of ethnic cleansing have occurred, the awareness that differences have inherent value prevents prejudice and stereotyping. "Some minorities may attempt to exclude others to maintain their own cultural unity. The most pronounced example is that of the former Republic of Yugoslavia" (Aslan, 2004: 13). Throughout the centuries, the Balkan peoples (the Southern Slavs, including Bosniaks, Montenegrins, Serbs, Croats and Slovenes as well as Turks, Albanians, Bulgarians, Balkan Jews, Balkan Romany and Wallachians (Romanians and Greeks)) with the experience of sharing the same culture, the same history, the same geography and the same fate, will only be able to free themselves from loss of identity and the construct of social distance if they are able to develop their social integration reflexes with the experiences of communication and negotiation.

During the socialisation phase, individuals learn that in their own societies they live with others who are different and unlike themselves and in the big picture that they are in the same frame and that basically, "us" and the "other" are complimentary concepts. In this process, social exclusion, the transmission of negative historical experiences, distancing and alienation are possible phenomena and are detrimental to social unity. The barriers in front of social unification can be overcome through communication, accepting differences mutually with tolerance as they are, with common ground approached in an equalitarian fashion. "Society is not a community consisting of uniform members who force their own identity on others. Adopting is not being withdrawn and/or closed towards the other but is accepting the other, making social boundaries open to everyone, especially those who are foreign to each other and those who wish to remain so" (Habermas, 2002; 9). 
Instead of excluding those who are different, perceiving existing difference as a source of value is the main factor in reinforcing social ties from a social standpoint. "If we want to protect peace in our country, our cities, our neighbourhoods and the world, if we want the variety within mankind to transform into a harmonious togetherness instead of a violent conflict, we need to get to know the "other" closely, even in our personal lives instead of superficially or shallowly. This is only possible by learning their cultures" (Maalouf, 2010: 143). In the world of today, where communication and transportation possibilities are increasing, where lifestyle choices are changing daily, the development of cultural right demands through democracy and the heterogeneous multicultural structures that have emerged within nearly every nation mean that the discourse of intercultural communication between the self and the other is even more necessary. The four main drivers of the concept of the other, prejudice, stereotyping, essentialism and culturism, may form the basis for alienation; however the different ethnic groups living in the Balkans, in the context of cultural, economic, social and political relations, in history and the present day, in the world conjecture, have many deep rooted common ties, coexistence practices and believing that events must be evaluated in the light of the existing conditions, have been able to free themselves from the perception of the other, promoting the coexistence structure and cultural communication, structuring solutions and living together in the most gentile area of the world for many centuries.

\section{CONCLUSION}

In the current century, considering the conditions of the time and the parameters existing, the concept of living with differences is becoming ever more important. The adoption of democratic and civilised attitudes to differences, in preventing alienation and the perception of the other, increasing dialogue and communication, making the culture of tolerance more widespread and realising that differences are to be treasured is very important. The awareness of living with variety is only possible with the reinforcement of the culture of coexistence and emphasis on common ground such as his- torical pasts, similarities and other aspects of joint life. Although the study is a multidisciplinary meta discourse analysis, we do not claim that from the Ottoman period to the modern Yugoslavian state and the rise of nations from the wreckage, on the stage of history, the Balkan nations were able to join together by eroding deep and complex differences, through centuries of interaction, emphasising similarities rather than differences, practising multiculturalism and coexistence to make social peace their only claim and hope. Indeed, the dominant culture is now more than ever, thanks to the increase of communication channels and the contributions of experience of practise, able to mediate and establish construction practise metaphors with communities and cultures that have been perceived by the other. At this point, intercultural communication becomes strong and significant in the replacement of alienating, excluding and discriminating discourse. Despite the differences, negative attitudes and discourse, the preparation of grounds for argumentative exposition, one of the most important aspects of coexistence, is highly important for the future of communities and cultures.

The Ottoman Empire was able to facilitate the coexistence of different ethnic groups within the Balkans in the context of the millet system, through the ummah approach and religious collective identities for more than five hundred years.

\section{REFERENCES}

Aslan, C. Birey-Toplum-Devlet Kavramlaştırma ve Ara Değişken Olarak Etnisite, Adana: Karahan Kitabevi.

Canatan, K. (2009). Avrupa Toplumlarında Çokkültürcülük: Sosyolojik Bir Yaklaşım; The Journal Of International Social Research, Volume, 2/6.

Çevik, A. (2010). Politik Psikoloji, Ankara: Dost Kitabevi Yayınları.

Doytcheva, M. (2013). Çokkültürlülük, Çeviren: Tuba Akıncılar Onmuş, İstanbul: İletişim Yayınları.

Habermas, J. (2002). Öteki Olmak, Ötekiyle Yaşamak, Çeviren. İlknur Aka. İstanbul: Yapı Kredi Yayınları.

Levinas, E. (1969). Totality and Infinity: An Essay on Exteriority. Çeviren: Alphonso Lingis. Pittsburgh, P.A. Duquesne University Press.

Lewis, B. (2000). Ortadoğu'nun Çoklu Kimliği. (Çev: M. Harmanc1). İstanbul: Sabah Kitapları.

Maalouf, A. (2010). Çivisi Çıkmış Dünya, İstanbul: Yapı Kredi Yayınları. 